\title{
Diseases in the Tabloids: Mapping Newspaper Narratives on Lassa Fever Epidemic in Nigeria
}

\author{
Joshua Aghogho Erubami ${ }^{1}$, Patience Elohor Oziwele ${ }^{1}$, Edith Ugochi Ohaja ${ }^{2}$, Martins Ndubisi Ezugwu² \& Uchenna \\ Chijindu Anorue ${ }^{2}$ \\ ${ }^{1}$ Department of Mass Communication, Delta State University, Abraka, Nigeria \\ ${ }^{2}$ Department of Mass Communication, University of Nigeria, Nsukka, Nigeria \\ Correspondence: Edith Ugochi Ohaja, Department of Mass Communication, University of Nigeria, Nsukka, Enugu \\ State, 410001, Nigeria.
}

Received: October 28, 2021

doi:10.11114/smc.v9i2.5414

\author{
Accepted: November 24, 2021 \\ Online Published: November 29, 2021 \\ URL: https://doi.org/10.11114/smc.v9i2.5414
}

\begin{abstract}
Lassa fever is a recurrent endemic disease in Nigeria with increasing seroprevalence in many parts of the country. In the absence of effective preventive vaccines, the mass media are being deployed as independent and complementary interventions to sensitise the public on appropriate measures for mitigating the spread of the disease. This study evaluates the different coverage patterns and frames that dominate newspaper narratives on Lassa fever epidemic in Nigeria. Multistage sampling technique was used to select 420 editions of six leading Nigerian newspapers published between January 2015 and December 2019. Findings showed that although the epidemic was frequently mentioned in newspaper articles, its coverage was mainly episodic with little media prominence, and its framing was too inadequate to compel the desired public health response. Hence, the study recommends that journalists and newspaper editors must dutifully engage in the publication of Lassa fever outbreak preparedness articles to significantly curb the spread of the disease in Nigeria.
\end{abstract}

Keywords: epidemic outbreak, infectious disease, media intervention, public health, risk communication

\section{Introduction}

Lassa fever remains a major public health challenge in many African countries, including Nigeria. The World Health Organisation ([WHO], 2017) estimates that the annual infection rate of the disease across Africa is about 100,000 to 300,000 , with approximately 5,000 deaths. Nigeria bears the highest burden of the disease with an estimated loss of 3,000 lives per year (Ibeabuchi, 2012; Wogu, 2018). The zoonotic disease causes a severe haemorrhagic fever that is characterised by sore throat, muscular aches, nausea, vomiting, chest pain and abdominal throbbing (Ogbu, Ajuluchukwu \& Uneke, 2007). The animal reservoir of the Lassa virus is Mastomys Natalensis, commonly known as the multimammate rat (Amodu \& Fapohunda, 2019).

Since the first isolation of the Lassa virus in 1969 in Lassa town of Borno State in North-eastern Nigeria, there has been a progressive increase in the seroprevalence rate of the disease in Nigeria, rising from a paltry 430 suspected cases in 2015 to 6,791 cases in 2020 (Nigeria Centre for Disease Control [NCDC], 2021). Stakeholders' efforts at tackling the spread of the disease have been significantly undermined by the absence of effective preventive vaccines which has remained elusive to the world for over 50 years after the discovery of the disease (WHO, 2017; Amodu \& Fapohunda, 2019). Hence, emphasis is being directed towards public sensitisation and enlightenment campaigns using different communication channels, including the mass media (Ogbu et al., 2003; Adefisan, 2014).

Generally, the mass media are potent tools for spreading health information and influencing public health behaviour (Bala, Strzeszynski \& Topor-Madry, 2017). Media messages can enhance public understanding of the course of an epidemic and simultaneously engender community-wide participatory changes in public knowledge and attitude towards health issues (Erubami, Bebenimibo \& Ugwuoke, 2021). Specifically, studies have shown that the newspaper medium can significantly influence public responses to general health challenges (Whitley \& Wang, 2017). This influence is due to the tendency of many people to rely on newspaper stories in the search for diverse health information (Gollust \& Lantz, 2009). In the course of such exposure, newspaper reports tend to influence public opinion through the careful selection and effective deployment of appropriate frames that highlight the salient aspects of a published article 
(Shih, Wijaya \& Brossard, 2008; Ajaero \& Anorue, 2018).

However, despite the consistent use of newspapers as independent and complementary interventions in the fight against the spread of Lassa fever (Wogu et al., 2019), research indicates that there is an inadequate improvement in public response and government commitment towards the prevention of the disease. For instance, government funding of Lassa fever health facilities in Nigeria is generally low, and public knowledge, attitudes and practices related to the prevention of the spread of the infection is poor (Adefisan, 2014; Adegoke, Ajibola \& Ogundairo, 2017; Wogu, 2018). The current scenario raises a poser on the effectiveness of newspaper narratives on Lassa fever-related issues in Nigeria. Thus, this study specifically seeks to (1) ascertain the prominence attached to Lassa fever news by Nigerian newspapers; (2) determine the main journalistic genres deployed by newspapers in the coverage of Lassa fever epidemic in Nigeria; and, (3) examine the diverse frames and discursive resources used in newspapers narratives on Lassa fever-related issues in Nigeria.

\section{Literature Review}

\subsection{The Concept of Media Framing}

The framing theory has become increasingly central to media analyses (Oriola, Ojomo \& Ajilore, 2017). The theory presupposes that the media can impact or influence audience feelings and tweak public perception of recommended actions towards social issues (Scheufele \& Lewenstein, 2005). This is based on the thinking that the highlighted aspects of a news story can trigger certain feelings or thought patterns in the minds of the audience and increase their likelihood of reacting to issues discussed in the media in a somewhat predictable way (Ajaero \& Anorue, 2018). Hence, to frame is to select certain aspects of a perceived reality and make them more salient in a communication text (Shih et al., 2008). Frames explain to the reader why an issue should be considered a problem, the possible causes of such a problem and the likely solution to it, thereby enhancing the ability of the audience to easily understand complex issues discussed in the media (Nwabueze \& Egbra, 2016).

The presumed inevitability of media framing rests on the belief that the larger audience is exposed to a vicissitude of uncoordinated information and may be less sophisticated to competently prioritise such barrage of information in line with general societal needs; hence, the need to carefully deploy media framing as a form of heuristics or cognitive shortcut to enable the audience make sense of complex issues on which they lack adequate coping experience (Scheufele \& Lewenstein, 2005). Generally, good media frames enable the audience to comprehend issues discussed in the media, assist journalists in the packaging of discrete events into whole news reports, and guide policy makers in the definition of policy options and decisions making (Oriola et al., 2017).

\subsection{Newspaper Framing of Public Health Narratives}

Increasing evidence indicates that many people rely on newspaper as their core source of information on diverse health-related issues (Bello, 2015; Whitley \& Wang, 2017). This suggests that the level of attention and type of interpretations (frames) given to health issues by newspapers may have some influence on the associated public response (Ajaero \& Anorue, 2018; Erubami, Bebenimibo \& Ohaja, 2021). As a result, the principles of framing have also been extensively deployed to understand how people perceive public health issues based on media interpretation and salience.

Generally, the newspaper medium is regarded as a credible source of health information, and the nature of newspaper narratives on public health issues tend to significantly influence the way the public perceives such issues (Bello, 2015). For instance, in the 1990s, the prevalence of non-HIV Sexually Transmitted Diseases (STDs) became a major public health challenge in the USA, with an estimated 15 million new cases every year. When Davidson and Wallack (2004) conducted a baseline study on how national newspapers' contents represented non-HIV STDs, their study showed that only $19 \%$ of the sampled articles mentioned the clinical and epidemiological courses of STDs; hence, the preponderance of non-HIV-related ignorance.

Wrong newspaper framing of mental health issues has also been found to be a correlate of poor public knowledge and perception of the problem. Whitley and Berry (2013) conducted a time series analysis to ascertain the trends in newspaper coverage of mental illness in Canada from 2005 to 2010 and found no significant positive change over the period in any of the measured domains. Their findings showed that negative stigmatising themes, such as danger, violence and criminality were the direct themes that resonated in the majority of articles analysed in the study, while the quality of mental health services, treatment for mental illness and mental illness recovery rates were sparingly mentioned, leaving readers with the wrong impression that the ailments were incurable.

In the first decade of the $21^{\text {st }}$ century, the health sector in Ghana topped the agenda of development challenges that needed to be urgently tackled (Gadzekpo, 2010), and the media were considered as one of the contributors to efforts aimed at tackling the challenge. When Diedong (2013) examined the various frames employed by three major Ghanaian 
national newspapers in the portrayal of public health issues between 2003-2005, it was found that newspaper articles were not adequately framed to encourage recommended health practices as the information and medical frames, which are crucial to empowering readers with correct health knowledge and information, were hardly noticeable in the majority of newspaper narratives on diseases.

\subsection{Newspaper Narratives on Public Health Challenges in Nigeria}

In Nigeria, several studies have established a correlation between newspaper dissemination of public health information and public health behaviours. Bello (2015) analysed 844 editions of four Nigerian national dailies to ascertain the coverage and representation of 45 public health issues in Northern Nigeria from 2010 to 2013. Using a triangulation method of content analysis, survey and in-depth interviews, the study concluded that health issues in Nigeria were grossly under-reported when compared to politics and the economy, and such under-reportage was responsible for the reduced media influence in directing needed public and government attention towards prioritising the health sector.

Observably, there has been an appreciable improvement in public knowledge and response to HIV/AIDS prevention and control efforts in Nigeria. This manifests in the increasing number of patients availing themselves of HIV/AIDS testing and case management. When Ciboh (2010) examined how the Nigerian print media framed health issues between 2007 and 2009, the results showed that HIV/AIDS was among the most frequently mentioned illnesses in newspapers. Furthermore, the sampled dailies adopted the information frame to create appropriate awareness and knowledge that motivated positive action against the spread of HIV/AIDS.

In 2014, there were confirmed cases of Ebola Virus Disease (EVD) in Nigeria. Although this initially caused a stir among the Nigerian public, the problem was effectively contained and its looming epidemic outbreak was successfully averted. Johnson, Layefa and Taiwo (2016) later investigated media performance to determine if newspapers contributed to the effective management of the disease. Their analysis of 214 editions of two Nigerian dailies provided evidence to conclude that the mass media were alive to their responsibilities as they deployed the reassurance frame to convince the public that the disease would soon be brought under control. The study also showed that newspapers made use of the information/awareness frames which kept the public abreast of efforts aimed at containing the disease, patients' response to treatment and appropriate coping mechanisms. A similar study conducted by Akpor and Alawari (2016) also affirmed that the information frame was utilised in newspaper narratives to enlighten the public on EVD trends.

The ensuing analyses explicitly show that how newspapers interpret and frame public health issues may significantly influence public response towards the issues; hence, it is imperative to investigate newspaper narratives on the nagging challenge of Lassa fever epidemic in Nigeria. Therefore, relying on previous theoretical and empirical findings, the current study proposed the following hypotheses;

H1: There is no significant difference in the level of prominence attached to Lassa fever news by Nigerian newspapers.

$\mathrm{H} 2$ : There is no significant difference in the journalistic genres deployed by newspapers in the coverage of Lassa fever epidemic in Nigeria.

H3: There is no significant difference in the frames and discursive resources used in newspaper narratives on Lassa fever-related issues in Nigeria.

\section{Method}

\subsection{Design}

The study adopted quantitative and qualitative content analysis to evaluate Lassa fever-related newspaper articles published by six major Nigerian national dailies (Vanguard, The Guardian, Punch, Daily Sun, Nigerian Tribune and The Nation) which were purposively selected on the basis of their national outlook, wide patronage, recognised professionalism, and consistent reportage of Lassa fever news (Wogu et al., 2019). The population of study consisted of all editions of the selected newspapers published from January $1^{\text {st }}, 2015$ to December $31^{\text {st }}, 2019$. This period covered the waxing, maintaining and waning phases of annual Lassa fever outbreaks in Nigeria. Lassa fever occurs in Nigeria throughout the year, but most cases are recorded during the dry season, especially between November and May (WHO, 2017). Thus, the total population of newspaper editions published within the period for the six selected dailies was 10,951 .

To ensure the representativeness of the sample, the study adopted the composite week sampling and continuous week sampling techniques. While the composite week sampling technique is generally considered to be less biased and superior to both the random sampling and continuous week sampling techniques (Obayi, Anorue \& Onyebuchi, 2016), the inclusion of a continuous week enabled the researchers to capture as many articles on Lassa fever as possible to enhance the interpretation of the patterns of newspaper representation of the disease. Since previous studies have shown 
that a minimum of six constructed weeks is adequate for a longitudinal health study of between one and five years (Luke, Caburnay \& Cohen, 2011), we selected a sample of six constructed weeks and six continuous weeks in line with Hero Stample's recommendation that a selection of 14 newspaper editions comprising constructed and continuous weeks can provide a representative sample for one year's worth of a newspaper's entire issues (Obayi et al., 2016). Consequently, we selected a total of 420 editions of the six newspapers spanning a five-year time frame. For the continuous week samples, a week was carefully selected from the 52 weeks in a year using the level of Lassa fever prevalence as the main criterion. For instance, in 2019, we selected week three which covered several Lassa fever related events, including the first international conference on Lassa fever held in Nigeria on January 16 and 17, 2019.

\subsection{Procedure}

To aid the article selection and coding processes, we operationalised Lassa fever reports as all newspaper stories (news, features, opinion, editorial and cartoons/graphics) that are related to the infection, causes, transmission, prevention, treatment, sensitisation and government/public response towards the disease. The extent of media prominence given to the disease was measured by the frequency of newspaper reportage of the epidemic as well as the position/placement given to newspaper articles concerning Lassa fever. That is, front cover, back page, centre spread or inside pages of the newspaper (Erubami, 2019). For our second research objective, journalistic genres were measured based on the format of the published newspaper article on Lassa fever: that is, straight news, features, opinions, editorials, letters-to-the-editor and cartoons/graphics (Ohaja, 2003; Smith, Smith \& Adedeji, 2017; Ajaero \& Anorue, 2018). To measure our third research objective, we operationalised media frames as the major discursive resources deployed by newspaper journalists/editors to highlight the salient aspects of an article, particularly the dominant issues contained in the lead of an article (Shih et al., 2008). Hence, relying on our pilot survey and previous studies on media framing of public health crises (Shih et al., 2008; Ciboh, 2010; Smith et al., 2017; Ajaero \& Anorue, 2018), we identified the following six framing typologies:

Table 1. Framing typologies for newspaper coverage of Lassa fever in Nigeria

\begin{tabular}{|c|c|}
\hline Frames & Definition \\
\hline Medical & $\begin{array}{l}\text { This is when an article essentially discusses the state of Lassa fever treatment facilities, the rate } \\
\text { of recoveries/mortality at treatment centres and how survivors of the epidemic are reintegrated } \\
\text { into the larger society. }\end{array}$ \\
\hline Action & $\begin{array}{l}\text { This is characterised by newspaper emphasis on the steps taken or ought to be taken to mitigate } \\
\text { the outbreak and/or spread of the disease. It includes such actions as ban on open air drying of } \\
\text { food items, rat consumption and compulsory sanitation of markets and other public places. }\end{array}$ \\
\hline Warning & $\begin{array}{l}\text { This frame covers stories with the main purpose of alerting the public to the looming outbreak } \\
\text { and/or spread of Lassa fever, especially at the beginning of the dry seasons. }\end{array}$ \\
\hline Reassurance & $\begin{array}{l}\text { This frame is seen in stories that encouraged the public against anxiety and fear, and emphasised } \\
\text { the readiness of concerned authorities to curb the spread of the disease. }\end{array}$ \\
\hline New evidence & $\begin{array}{l}\text { This refers to articles that featured new scientific findings on the clinical and epidemiological } \\
\text { course of Lassa fever, including the discovery of new strains and transmission patterns of the } \\
\text { disease. Issues of preventive and curative vaccines are also covered in this frame. }\end{array}$ \\
\hline Consequence & $\begin{array}{l}\text { This refers to stories focusing on the human, social and economic burden arising from the } \\
\text { outbreak of Lassa fever. Other consequences, such as restraint from attending to infected } \\
\text { relatives and stoppage of risk behaviours, are also reflected in this frame. }\end{array}$ \\
\hline
\end{tabular}

\subsection{Coding and Inter-Coder Reliability}

Data for the study were collected using a coding sheet that reflected appropriate content categories and units of analysis for the study. The inter-coder reliability coefficient was determined using Hosti's (1969) formula which is the most widely used technique in behavioural literature (Ajaero \& Anorue, 2018; Erubami, 2019). Prior to the actual data collection exercise, two of the researchers independently coded the 2019 editions of the six selected newspapers, representing $20 \%$ of the total samples. On average, the results yielded an inter-coder reliability coefficient of .87 which is greater than the minimum benchmark of $\geq 0.70$ (Erubami, 2019). The reliability scale of each frame was also above the minimum benchmark: medical frame (.96), action frame (.85), warning frame (.91), new evidence frame (.79) and consequence frame (.84).

\subsection{Data Analysis}

The results were analysed using descriptive statistics of tabulated frequency counts and percentages, while textual 
analysis was used to build coherent themes/frames on newspaper coverage of Lassa fever. To test the hypotheses, SPSS version 23 was used to conduct Pearson Chi Square $\left(X^{2}\right)$ Test of Independence to determine whether there were significant differences between the observed and expected frequencies in the collected data. Probability value for the study was determined at $<.05$ significance level.

\section{Results}

\subsection{Prominence of Newspaper Narratives on Lassa Fever Epidemic in Nigeria}

The results presented in Table 2 show that the outbreak of Lassa fever and its associated challenges are adequately covered by newspapers in Nigeria; however, newspaper articles on the disease are seldom given adequate media prominence. A total of 391 articles related to the disease were found in the 420 editions that were analysed for the five-year period, but in terms of placement, the majority of the stories $(\mathrm{N}=328,83.9 \%)$ were tucked in the inside pages of the six newspapers, $8.2 \%(\mathrm{~N}=32)$ were published on the front page, $7.4 \%(\mathrm{~N}=29)$ were placed on the centre spread, while a paltry $0.5 \%(\mathrm{~N}=2)$ of all the articles featured on the back page of the six national dailies.

To test our first hypothesis, $X^{2}$ test of independence was conducted to determine whether all the studied newspapers had equal preferences in the prominence attached to Lassa fever related articles in terms of page placement. The results presented in Table 3 show that there was no significant difference in the page placement of stories related to the disease across the studied dailies, $X^{2}(15, N=391)=9.672, p=.840$. As shown in Table 2, all the newspapers followed a similar pattern of publishing Lassa fever-related stories on the inside pages $(\mathrm{N}=328,83.9 \%)$. Hence, the assumption of H1 was supported.

Table 2. Newspaper articles on Lassa fever according to placement, genres and frames

\begin{tabular}{|c|c|c|c|c|c|c|}
\hline \multirow[t]{2}{*}{ Placement } & Front cover & Back page & Spread & Inside pages & & \\
\hline & $32(8.2 \%)$ & $2(0.5 \%)$ & $29(7.4 \%)$ & $328(83.9 \%)$ & & \\
\hline \multirow[t]{2}{*}{ Genre } & News & Features & Opinions & $\begin{array}{l}\text { Letters-to-the-e } \\
\text { ditor }\end{array}$ & Editorials & Graphics \\
\hline & $294(75.2 \%)$ & $59(15.1 \%)$ & $23(5.9 \%)$ & $2(0.5 \%)$ & $7(1.8 \%)$ & $6(1.5 \%)$ \\
\hline \multirow[t]{2}{*}{ Frames } & Medical & Action & Warning & Consequence & $\begin{array}{l}\text { New } \\
\text { evidence }\end{array}$ & Reassurance \\
\hline & $42(10.7 \%)$ & $112(28.7 \%)$ & $31(7.9 \%)$ & $158(40.4 \%)$ & $30(7.7 \%)$ & $18(4.6 \%)$ \\
\hline
\end{tabular}

4.2 Journalistic Genres in Newspaper Narratives on Lassa Fever Epidemic In Nigeria

Across all the studied national dailies, straight news was the dominant format deployed in the coverage of Lassa fever epidemic in Nigeria. As shown in Table 2, 75.2\% $(\mathrm{N}=294)$ of all articles related to the disease were reported as straight news, $15.1 \%(\mathrm{~N}=59)$ were published as feature articles, $5.9 \%(\mathrm{~N}=23)$ were opinion articles, $0.5 \%(\mathrm{~N}=2)$ were editorials, $1.8 \%(\mathrm{~N}=7)$ were letters-to-the-editor, while $1.5 \%(\mathrm{~N}=6)$ were cartoons. To test hypothesis two, we conducted $X^{2}$ test of independence to ascertain if the genres adopted by newspapers in the coverage of Lassa fever epidemic in Nigeria varied significantly among the studied tabloids. According to the results of the analysis presented in Table 3, there was no significant difference in the journalistic genres adopted by the studied newspapers in the reportage of Lassa fever outbreaks, $X^{2}(25, N=391)=31.722, p=.166$. Specifically, Table 2 shows that the majority of Lassa fever articles were published in the straight news format $(\mathrm{N}=294,75.2 \%)$. Therefore, the assumption of $\mathrm{H} 2$ was supported.

Table 3. Chi Square Test of Independence

\begin{tabular}{lllll}
\hline Ha & Pearson Chi-Square Value & $d f$ & $N$ & $P$ \\
\hline $\mathrm{H}_{1}$ & 9.672 & 15 & 391 & .840 \\
$\mathrm{H}_{2}$ & 31.722 & 25 & 391 & .166 \\
$\mathrm{H}_{3}$ & 162.765 & 25 & 391 & $<.001$ \\
\hline
\end{tabular}

Ha = Hypotheses; $d f=$ Degree of freedom; $N=$ Number of valid cases; $P=$ Asymptotic Significance

\subsection{Newspaper Framing of Lassa Fever Epidemic in Nigeria}

The data presented in Table 2 indicate that the consequence frame $(\mathrm{N}=158,40.4 \%)$ and action frame $(\mathrm{N}=112,28.7 \%)$ were the major salience and principal discursive resources that resonated in most newspaper narratives related to Lassa fever epidemic in Nigeria. This was followed by the medical frame $(\mathrm{N}=42,10.7 \%)$, warning frame $(\mathrm{N}=31,7.9 \%)$, new evidence frame $(\mathrm{N}=30,7.7 \%)$ and reassurance frame $(\mathrm{N}=18,4.6 \%)$. Accordingly, for our third hypothesis, we 
used $X^{2}$ test of independence to evaluate whether there is a significant difference in the frames and discursive resources deployed by newspapers in media narratives related to Lassa fever epidemic in Nigeria. The results of the analysis shown in Table 3 indicate that there is a significant difference in the framing of the diseases among the studied dailies, $X^{2}(25, N=391)=162.765, p<.001$. Table 2 shows that the studied tabloids adopted significantly different frames in the publication of Lassa fever-related articles with the consequence $(\mathrm{N}=158,40.4 \%)$ and action $(\mathrm{N}=112,28.7 \%)$ frames topping the charts. Accordingly, the assumption of $\mathrm{H} 3$ was rejected.

\section{Discussion}

Our study sought to map newspaper narratives on Lassa fever epidemic in Nigeria by investigating the extent of coverage and nature of framing given to the disease by six leading Nigerian newspapers. Upon the careful analysis of 420 newspaper editions selected for the study, the results showed that the disease has been frequently reported by newspapers in the past five years (2015-2019), given that no fewer than 391 articles mentioned the epidemic with reference to its infection rates, causes, transmission, fatality ratio, recovery rate and public response, among other issues. Thus, our findings lend credence to previous studies which showed that the Lassa fever epidemic is being adequately covered by the Nigerian press (Smith et al., 2017).

Despite this wide coverage, however, newspaper articles on the disease seldom enjoyed media prominence. About $83.9 \%$ of stories on the disease were published on the inside pages of the newspapers, especially on the metro and health news pages, and this approach did not vary significantly across the six studied national dailies. Only $8.2 \%$ of articles related to the disease were published on the front cover of the newspapers, $7.4 \%$ which were mainly feature articles were published on the centre pages, while $0.5 \%$ of the articles were published on the back page. The result is consistent with previous studies which found that most health-related stories are tucked in the inside pages with little or no media prominence (Ajaero \& Anorue, 2018). In apportioning prominence to societal issues, newspaper editors usually place perceived important issues on strategic pages where they can be easily seen (Ohaja, 2003; Obayi et al., 2016). In this regard, the front cover is considered the most prominent page in a newspaper because it serves as the first point of attraction to the reader. This is followed by the back cover, the centre pages and the inside pages in a descending hierarchy (Erubami, 2019).

Generally, straight news was the dominant genre used by newspapers in the coverage of Lassa fever epidemic in Nigeria, and the results of our $\mathrm{X}^{2}$ analysis showed that the adoption of this reportorial format did not vary significantly across the six national dailies studied. This indicates that newspaper narratives related to Lassa fever were mainly event-based, with minimal thematic frames that offered detailed extrapolation on the clinical and epidemiological courses of the disease. The current finding is consistent with previous research which showed that media coverage of health issues are generally episodic and tied to the occurrence of events, given that many newspaper editors tend to wait for the occurrence of negative health events before reporting them (Shih et al., 2008; Ajaero \& Anorue, 2018). The insignificant number of letters-to-the-editor $(\mathrm{N}=7,1.8 \%)$ that was published by the newspapers also indicates a low level of public involvement in media discussions on the outbreak of Lassa fever epidemic in Nigeria. Usually, letters-to-the-editor provide the ample opportunity for media audience to push down their opinion to the larger public and suggest ways in which pertinent social challenges can be effectively managed.

Finally, our study showed that the consequence and action frames were the major discursive resources used by newspapers in the reportage of Lassa fever epidemic in Nigeria. However, the results of the $\mathrm{X}^{2}$ analysis suggest that the adopted frames in newspaper narratives related to Lassa fever epidemic in Nigeria varied significantly across the studied tabloids. Consistent with previous research (Shih et al., 2008; Ajaero \& Anorue, 2018), the majority of the analysed articles $(\mathrm{N}=158,40.4 \%)$ generally focused on the human, social and economic losses arising from the outbreak of Lassa fever (consequences), just as a significant amount of the reports $(\mathrm{N}=112,28.7 \%)$ reflected the steps taken or ought to be taken by relevant authorities and the public to mitigate the outbreak and/or spread of the disease (action). One of such actions was the first international conference on Lassa fever organised by the NCDC in January 2019. On the consequence frame, one of the analysed news articles titled "Lassa fever kills 1,047 Nigerians" read thus:

Over the past 50 years, Lassa fever has become a disease occurring in perennial outbreaks in nearly all the 36 states of Nigeria, with increasing numbers of suspected cases, dry season peaks, and unacceptably high case fatality rates... Nigeria should declare Lassa fever disease a public health event of national emergency.

Similarly, another article titled "Ondo distributes 10,000 rat poisons as Lassa fever spreads" essentially reflected the action taken by the government to curb the spread of the disease in Nigeria. A part of the news article read thus:

Ondo State Government has distributed 10,000 rat poisons to residents of Ogbese in Akure North to kill rats in the community to curb the spread of Lassa fever...Over 3,000 rats were killed in Owo town after the state government distributed poison to the residents. 
Despite the significant difference in the framing patterns adopted by the studied newspapers, the dominance of the two frames across the six national dailies supports arguments that journalists tend to deploy similar themes in the coverage of the same events (Bennet, 2001). The focus on the consequence and action frames also suggests that journalists and newspaper editors pay greater attention to the substantive aspects of epidemics unlike controversial scientific issues that tend to get dramatised through journalistic reporting (Nisbet \& Huge, 2006).

Our analyses show that the warning frame $(\mathrm{N}=31,7.9 \%)$ was sparingly used in newspaper articles on the Lassa fever epidemic; hence, the public did not get adequate media reminder on impending outbreaks of the disease. It is also likely that the media did less in discouraging the public from certain risk behaviours and environmental practices that predispose people to contracting Lassa fever disease. The pertinence of the warning frame in media health reports is reflective of the surveillance/watchdog role of the press which entrusts the media with the responsibility of identifying looming dangers and alerting the public to their possible occurrence (Erubami, Bebenimibo \& Ugwuoke, 2021). Considering that the annual waxing and maintenance phases of Lassa fever are experienced between November and May (WHO, 2017), the least the media could do is to consistently remind the public on the imminent danger arising from a possible outbreak of Lassa fever.

Also, consistent with previous studies (Diedong, 2013), the medical and new evidence frames only resonated in a few articles on Lassa fever. Although the conspicuous absence of articles on new evidence could be explained by the general snail-pace progress in scientific breakthroughs related to the development of effective human vaccines for the prevention and management of the disease, the infrequent deployment of the medical frame suggests that the media did less in addressing the challenges related to poor government funding of Lassa fever treatment facilities which are generally inadequate and in dire need of urgent government attention (Adefisan, 2014; Adegoke et al., 2017; Wogu, 2018).

\section{Conclusion}

Newspapers are critical to the process of creating public awareness on infectious diseases, such as Lassa fever. Our study has shown that issues related to the outbreak of Lassa fever epidemic in Nigeria are frequently covered by Nigerian newspapers, but such issues seldom enjoy the desired media prominence that may compel appropriate public response towards the effective prevention of the disease's outbreak. Also, newspaper narratives on Lassa fever epidemic in Nigeria were largely episodic and event-based with limited thematic discussions that could enhance public understanding of the risks associated with the disease. Similarly, the study affirmed that newspaper narratives on the disease are mainly mirrored through the consequence and action frames, while the medical and warning frames seem to be less popular among journalists and editors with reference to Lassa fever discourse. Thus, the findings underscore the need for journalists and newspaper editors to dutifully perform their surveillance roles by publishing Lassa fever outbreak preparedness articles to significantly curtail the spread of the disease in cases of its outbreak. Importantly too, media practitioners are encouraged to be more proactive in their choice of salience and frames for articles on public health crises, such as Lassa fever.

\section{References}

Adefisan, A. K. (2014). The level of awareness that rat is a vector of Lassa fever among the rural people in Ijebu-North Local Government, Ogun State, Nigeria. Journal of Education and Practice, 5(37), 166-170.

Adegoke, O. O., Ajibola, O. F., \& Ogundairo, J. A. (2017). Knowledge, attitude and practices of foodstuff sellers on Lassa fever in major markets in Ibadan. African Journal for the Psychological Study of Social Issues, 20(2), $165-176$.

Ajaero, I. D., \& Anorue, L. (2018). Newspaper framing and climate change mitigation in Nigeria and Ghana. African Population Studies, 32(2), 4228-4239. https://doi.org/10.11564/32-2-1195

Akpor, E. D., \& Alawari, C. (2016). Media coverage of Ebola virus disease in Nigeria using Guardian and Punch newspapers. International Journal of International Relations, Media and Mass Communication Studies, 2(2), 41-50. Retrieved from

https://www.eajournals.org/journals/international-journal-international-relations-media-mass-communication-studi es-ijirmmcs/vol-2-issue-2-may-2016/media-coverage-ebola-virus-disease-nigeria-using-guardian-punch-newspape rs/

Amodu, S. E., \& Fapohunda, S. O. (2019). Lassa fever and the Nigerian experience: A review. European Journal of Biological Research, 9(3), 155-164. https://doi.org/10.5281/zenodo.3382695

Bala, M. M., Strzeszynski, L., \& Topor-Madry, R. (2017). Mass media interventions for smoking cessation in adults. Cochrane Database System Reviews, (11), CD004704. https://doi.org/10.1002/14651858.CD004704.pub4 
Bello, S. M. (2015). Newspaper coverage of health issues in Nigeria: The frequency of reporting malaria, HIV/AIDS and polio and the effect of seeking health information on the health behaviours of newspaper readers (Doctoral dissertation, University of Canterbury, Christchurch, New Zealand). Retrieved from http://ir.canterbury.ac.nz/handle/10092/11639

Bennett, L. W. (2001). News: The politics of illusion. New York, NY: Addison Wesley Longman.

Ciboh, R. (2010). Newspaper coverage of health issues in Nigeria. The Nigerian Journal of Communication, 8(1), 220-241.

Davidson, A. E., \& Wallack, L. (2004). A content analysis of sexually transmitted diseases in the print news media. Journal of Health Communication, 9(2), 111-117. https://doi.org/10.1080/10810730490425268

Diedong, A. I. (2013). Covering health issues: The role of newspapers in Ghana. International Journal of Humanities and Social Science, 3(12), 46-51. Retrieved from http://www.ijhssnet.com/journals/Vol_3_No_12_Special_Issue_June_2013/5.pdf

Erubami, J. A. (2019). Economic fluctuations and newspaper advertising expenditures during and after the Nigerian economic recession. Sahel Analyst: Journal of Management Sciences, 17(3), 37-51. Retrieved from https://saheljournalsonline.org.ng/jmsyear_2019_3.html

Erubami, J. A., Bebenimibo, P., \& Ohaja, E. U. (2021). Newspaper exposure, efficacy feeling and political apathy among youths in South-east Nigeria. Pertanika Journal of Social Sciences \& Humanities, 29(3), 1611-1629. https://doi.org/10.47836/pjssh.29.3.08

Erubami, J. A., Bebenimibo, P., \& Ugwuoke, J. C. (2021). Social media use and Covid-19 risk perception among Nigerians: The roles of affects, gender and information sources. Media Watch, 12(2), 316-332, https://doi.org/10.15665/mw/2021/v12i2/160154

Gadzekpo, A. (2010). Global warning or global warming? The framing of climate change discourses in Ghanaian newspapers. Ghana Social Science Journal. 7(1), 72-88.

Gollust, S. E., \& Lantz, P. M. (2009). Communicating population health: Print news media coverage of type 2 diabetes. Social Science \& Medicine, 69(7), 1091-1098. https://doi/10.1016/j.socscimed.2009.07.009

Ibeabuchi, C. (2012, March 26). Lassa fever kills 3,000 Nigerians annually. Vanguard Newspaper. Retrieved from http://www.vanguardngr.com/2012/03/lassa-fever-kills-3000-nigerians-annaully/amp/

Johnson, W. A. Layefa, G. \& Taiwo, A. (2016). The press and social responsibility: Newspaper coverage of the 2014 Ebola virus disease outbreak in Nigeria. Journal of Humanities and Social Science, 21(6), 7-14. https://doi/10.9790/0837-2106010713

Luke, D. A., Caburnay, C. A., \& Cohen, E. L. (2011). How much is enough? New recommendations for using constructed week sampling in newspaper content analysis of health stories. Communication Methods and Measures, 5(1), 76-91. https://doi.org/10.1080/19312458.2010.547823

Nigeria Centre for Disease Control (2021). Lassa fever situation report, Epi week 53: 28 December 2020 - 03 January 2021. Abuja, Nigeria: NCDC. Retrieved from

https://ncdc.gov.ng/diseases/sitreps/?cat=5\&name=An\%C2\%A0update $\% \mathrm{C} 2 \% \mathrm{~A} 0$ of $\% \mathrm{C} 2 \% \mathrm{~A} 0$ Lassa $\% \mathrm{C} 2 \% \mathrm{~A} 0$ fever $\% \mathrm{C} 2 \% \mathrm{~A} 0$ outbreak\%C2\%A0in\%C2\%A0Nigeria

Nisbet, M. C., \& Huge, M. (2006). Attention cycles and frames in the Plant Biotechnology Debate: Managing power and participation through the press/policy connection. Harvard International Journal of Press/Politics, 11(2), 3-40. https://doi.org/10.1177/1081180X06286701

Nwabueze, C., \& Egbra, S. (2016). Newspaper framing of climate change in Nigeria and Ghana. Applied Environmental Education and Communication, 15(2), 111-124. https://doi.org/10.1080/1533015X.2016.1164094

Obayi, P. M., Anorue, L. I., \& Onyebuchi, C. A. (2016). Demystifying content and data analysis in social science research. Enugu, Nigeria: Madonna Printing and Publishing House.

Ogbu, O., Ajuluchukwu, E., \& Uneke, C. J. (2007). Lassa fever in West African sub-region: An overview. Journal of Vector-Borne Diseases, 44, 1-11.

Ohaja, E. U. (2003). Mass media research and project report writing. Surulere, Nigeria: John Letterman.

Oriola, M. O., Ojomo, O., \& Ajilore, K. (2017). Relationship between newspaper framing and public perception of Buhari's anti-corruption crusade in Nigeria. International Journal of Scientific Research in Educational Studies \& Social Development, 2(1), 76-93. 
Scheufele, D., \& Lewenstein, B. (2005). The public and nanotechnology: How citizens make sense of emerging technologies. Journal of Nanoparticle Research, 7(6), 659-667. https://doi.org/10.1007/s11051-005-7526-2

Shih, T., Wijaya, R., \& Brossard, D. (2008). Media coverage of public health epidemics: Linking framing and issue attention cycle toward an integrated theory of print news coverage of epidemics. Mass Communication \& Society, 11, 141-160. https://doi/10.1080/15205430701668121

Smith, S., Smith, S., \& Adedeji, A. (2017). The influence of the Nigerian newspaper on Lassa fever reportage. The International Journal of Communication and Health, 11, 76-86.

Whitley, R., \& Berry, S. (2013). Trends in newspaper coverage of mental illness in Canada: 2005-2010. Canadian Journal of Psychiatry, 58 (2), 107-112. https://doi/10.1177/070674371305800208

Whitley, R., \& Wang, J. W. (2017). Good news? A longitudinal analysis of newspaper portrayals of mental illness in Canada 2005 to 2015. Canadian Journal of Psychiatry, 64 (4), 278-285. https://doi/10.1177/0706743716675856

Wogu, J. O. (2018). Mass media awareness campaign and the prevention of the spread of Lassa fever in the rural communities of Ebonyi State, Nigeria: Impact evaluation. Journal of Public Health in Africa, 9(882), 179-184. https://doi/10.4081/jphia.2018.882

Wogu, J. O., Chukwu, C. O., Nwafor, K. A., Anikpe, E. A., Ugwuoke, J. C., Ugwulor-Onyinyechi, C. C., \& Eseadi, C. (2019). Mass media reportage of Lassa fever in Nigeria: A viewpoint. Journal of International Medical Research, O(0) 1-7. https://doi.org/10.1177/0300060518821552

World Health Organisation (2017). Lassa fever: Key facts. Retrieved from http://www.who.int/news-room/fact-sheets/detail/lassa-fever

\section{Copyrights}

Copyright for this article is retained by the author(s), with first publication rights granted to the journal.

This is an open-access article distributed under the terms and conditions of the Creative Commons Attribution license which permits unrestricted use, distribution, and reproduction in any medium, provided the original work is properly cited. 